\title{
The Plague at Ashdod
}

\author{
Christian Conrad PhD, Connie Nugent MLS
}

The word "plague" appears in Exodus 11, when the Lord said to Moses, "I will bring one more plague upon Pharaoh and upon Egypt.... Every first born in the land of Egypt shall die..., and all the first born of the livestock." The term "plague" has been used to describe epidemics and pandemics of infectious disease, agricultural disasters such as crop destruction by locusts, and overpopulation of animals that causes profound ecological disturbances. For example, the Black Death occurred in Europe and Asia in the $14^{\text {th }}$ century, and the Great Plague occurred in London in 1665. These pandemics were likely caused by the bacterium Yersinia pestis.

In 1631, French artist Nicholas Poussin painted an image of the plague-stricken people of Ashdod (now in Israel). The oil painting, which reflects a biblical narrative, shows the aftermath of the people placing the Ark of the Covenant into the Temple of Dagon. In the far left of the center of the canvas, we can see the Ark and a statue smashed into several pieces. The effects of the plague, created by God as a punishment for worshiping a false idol, can be seen in the foreground. The figures in the foreground who are stricken by the plague almost appear to be in black and white, with the majority of the color removed from their depiction. In the background, two figures carry away a victim, noticeable even from a distance due to the victim's lack of color. The Temple of Dagon itself was later destroyed by Samson (Judges 16).

Although the original painting by Poussin can be found in the Musée du Louvre, Paris, curiously there is an almost exact replica located in the National Gallery of the United Kingdom. This second version was painted by Angelo Caroselli, a noted copyist of the time. Caroselli's rendition features an exact copy

Corresponding author: Christian Conrad PhD Contact Information: Conradmerz@yahoo.com DOI: $10.12746 /$ swrccc.v5i21.418

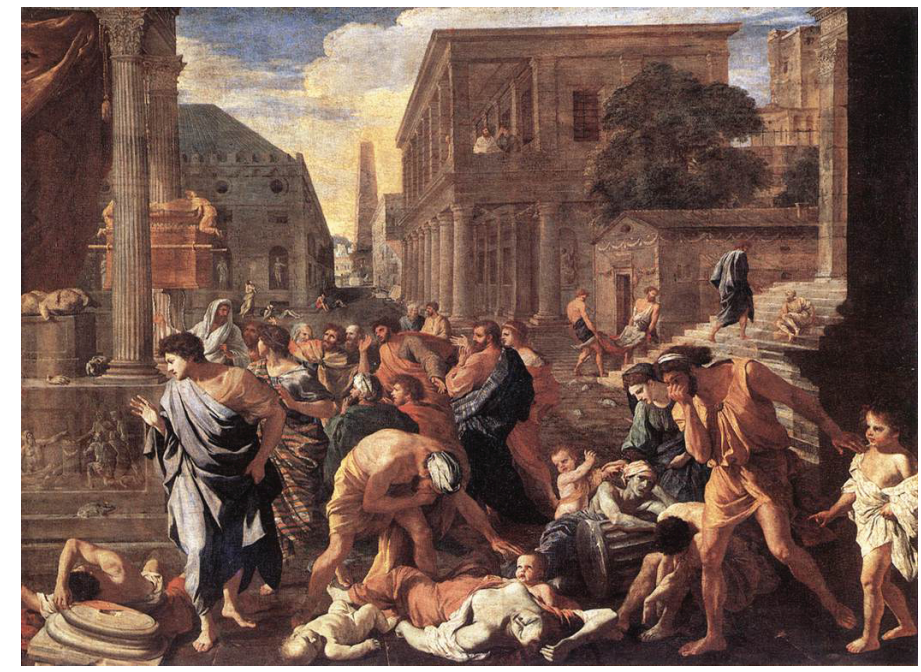

of the figures with an alteration to the background buildings. What becomes even more fascinating is that both versions of the painting were owned by the same patron, Fabrizio Valguarnera, and Caroselli's copy was most likely created as the same time as the original. The copy was paid for by money obtained in a jewel heist, and with many other copies and original paintings in the possession of Valguarnera, the second version might have had a nefarious intent.

Author affiliations: Christian Conrad PhD -Museum of Texas Tech University, Lubbock, TX; Connie Nugent MLS-Department of Internal Medicine, TTUHSC, Lubbock, TX

Submitted: 9/4/2017

Conflicts of interest: none

\section{REFERENCES}

1. https://www.nationalgallery.org.uk/artists/nicolas-poussin

2. https://www.nationalgallery.org.uk/paintings/angelo-carosellithe-plague-at-ashdod-after-poussin

3. https://www.nationalgallery.org.uk/paintings/research/theplague-at-ashdod 